valuable paper on newer electrodo systems; and Kemula outlines his now woll-known chromatopolarographic technique. Milner's succinct description of sample treatment should provo of greatest value to practising analysts.

The second volume concludes with several readable chapters by various specialist authors on the applications of polarography to metallurgical, pharmaceutical, biochernical and other relatod forms of analysis.

There can be little doubt that as is collection of up-to-date reviews of scientific advances in this ubiquitous field, this publication will win much acclaim from those serious disciples of the Heyrovsky mothod.

D. T, LEwIS

\section{AN INTRODUCTION TO MAMMALS}

Introduction to Mammalogy

By Prof. E. Lendoll Cockrum. Pp. viii +455 . (Now York: The Ronald Press Company, 1962.) 9 dollars.

\section{Laboratory and Field Manual for Introduction to} Mammalogy

By Prof. E. Lendell Cockrum. Second edition. Pp, v+116. (New York : The Ronald Press Company, 1962.) 4 dollars.

7 HE production of a book designed primarily

for college studonts and entitled Introduction to Mammalogy would seem to be an ideal opportunity to corroct the impression frequently given by an orthodox, elementary, vertebrate course that tho class Mammalia consists of rabbits and rats (with dogs' skulls). The book is divided into two sections, the first comprising six chapters on the "Biology of Mammals", and tho second a systematic treatment of the class with an account of cach family. Both parts leave much to be desirod. The first section is indeed a useful and comprehensive account of general manmalogy, but it seems a pity that the opportunity was not taken to omit much that can be found in any vertebrate text-book, and include more information on moro strictly mammalian characteristics. Much space is occupied by trivialities, for example, the same space (one paragraph) is taken to describe the fluorescence of some pelagos under ultra-violet light as to describe the scent-glands, which play a dominant part in the life of most species of mammals. Inaccuracies abound; for example, in the labellod illustration of a skull (coyote) the zygomatic arch is called the rostrum and the mandible the maxilla.

The systematic section would be an invaluable compilation if it were accurate. In fact errors occur on page after page. Each family is accompanicd by a map of its world distribution, most of which show gross inaccuracies. For example, the Dasypodidae (armadillos) are shown to be confined to the northeastern half of South America, when in fact they reach Patagonia; apos are shown on the East African coast; the Indian river dolphin is correctly described in the text as being confinod to the Rivers Ganges, Brahmaputra and Indus, but althongh these rivors are cloarly indicated on the map they are left blank, while southern peninsular India is shaded: rhino. ceroses are indicated as absent from both India and West Africa, which fortunately is not yet the case; and squirrols aro shown to be absont from West Africa, a situation that would save many a taxonomic head. ache if it wore true. The text is scarcely more reliable. The statemont that the gaur (the Indian wild ox) is a typical African species is enough to dispel any confidence in any of the great mass of potentially valuable information contained in this volume.

The accompanying laboratory and field manual contains keys to the genera of North American mammals and many useful suggestions for practical work. But the exercise of filling in blanks with observations is scarcely likely to develop an original, inquiring approach to any subject.

\author{
G. B. Corbet
}

\section{PATHOLOGY OF TREES AND SHRUBS IN BRITAIN}

Pathology of Trees and Shrubs

With special reference to Britain. By T. R. Poace. Pp. $\mathrm{xx}+723+16$ platcs, (Oxford: Clarendon Press, 1962.) $90 s$.

7 TIS is no mere description of diseasos of trees and shrubs. It is far more than that, and it is so compilod and written that it will be of great, value to those interested in the pathology of trees and shrubs, bo they forester, student or resoarch worker.

More than one-third of the book is devoted to an exposition of the various agenoies which may causes damage to troes such as climate, unsuitable edaphic conditions, man, animals, insocts and plants. This section includes well-written summaries of diseases of goneral importance in the nursery and on stems, shoots and leaves. Then follow chapters on the diseases of forest troos grown in Britain and a chaptor on tho diseases of ornamental trees and shrubs. Control, pruning, treo surgery and quarantine measures are adequately dealt with and there is a valuable list of host species. All this information is due to the author's own experionce in Britain, in Europe and in North America, and to his having consulted a vast amount of world literature. The listed bibliography amounts to noarly 2,500 entries and this section alono will be of groat worth to research workers and others requiring more detailed information about a particular subject.

Although one agreos to a certain extent with the author's contention about changes in botanical nomonelature, it is a pity that he has held out so strongly against such names as Picea abies and Quercus petraea, which even most diehards have accepted, oxcept perhaps some French foresters.

The author is quite emphatic about not attempting to provide keys for identification purposes. Tho book is concerned with the symptoms and diagnosis of tree diseases and therefore dotails of spore-sizes and microscopic anatomy of fruit-bodies have no useful place in it and would add considerably to the book's already large size if they had been included.

In the preface Peace feols that he may have been over-ambitions in attempting to cater for a wide range of needs. No apology is required, for a wark of this kind has long been wantod. It has succooded by the material provided and by the way it has been presented and illustrated. Tom Peace was chief research officer of the Forestry Commission. This book is a worthy memorial to his work. His untimely dcath last September more or lese coincided with the date of publication. 